\title{
Water Quality Assessment of Njaba River, Nigeria
}

\author{
Akubugwo E. $I^{1}$, Nwachukwu M.I ${ }^{2}$, Odika P.C ${ }^{3}$, Duru M.K.C $*^{4}$ \\ ${ }_{1,3,4}$ (Department of Biochemistry/ Abia State University, Uturu, Nigeria) \\ ${ }_{2}^{2}$ (Department of Microbiology/ Imo State University, Owerri, Nigeria)
}

\begin{abstract}
The water quality of Njaba River was assessed using standard methods. Results obtained revealed the presence of colour $(17.07 \pm 1.04-22.16 \pm 0.89$ units), total solid $(500.00 \pm 1.08-5000.00 \pm 0.96 \mathrm{mg} /)$, total dissolved solid $(400.0 \pm 0.55-4,000.00 \pm 0.34 \mathrm{mg} / \mathrm{l})$, total suspended solid $(100.00 \pm 0.29-1,000.00 \pm 0.87)$, heavy metals such as mercury $(0.002 \pm 0.01-0.006 \pm 0.01)$, lead $(0.004 \pm 0.01-0.07 \pm 0.00 \mathrm{mg} / \mathrm{l})$ and high microbial load in the studied river water. The high levels of these parameters indicated the poor quality of Njaba River water, and should not be consumed without purification. The present study has shown the water quality of Njaba River, Imo State, Nigeria.

Keywords - Heavy metals, Njaba River, physicochemical parameters, pollution
\end{abstract}

Accepted Date: 17 June 2013

\section{INTRODUCTION}

Experts simply defined water pollution as any physical or chemical change in water that may adversely affect organisms [1-3]. Although water pollution is a global problem but the type of pollution varies according to country's level of development hence countries with high population growth rate and poor waste management system tend to generate more waste that pollute the environment than those once with low population growth rate and standard waste management system [4]. Akaninwor and Egwim [5] noted that water is polluted when its accepted quality has been altered by man`s activities through anthropogenic input such that its intended usage for commercial or domestic purpose is hampered. In developing and undeveloped countries, water pollution is among the most common form of environmental pollution [6].

Nigeria as a developing nation has witnessed unprecedented form of water pollution. Different studies on the existing forms of water body in the country has shown that aside underground water as the case with spring water [7], most Nigeria water bodies are polluted [8-12]. Surface water bodies are the worst hit by this nefarious act of man within the country [13-15]. Aside the pollutants introduced by man and nature, flood carry chemicals from farm lands, and waste materials on land, and empty them into surface water bodies especially during heavy rainfall [6].

Njaba River is one of such surface water bodies in Nigeria that receive pollutants from flood aside the once introduce by man and nature. Njaba River originated from the north-western part of Isu at Isunjaba, flows south-westwards through Njaba and Oguta territories towards Oguta lake, passing through the southern parts of Ukworji, Umunnoha and Oguta Local Government Areas. Njaba River found in Niger Delta basin of Nigeria, lies within Latitudes $5^{\circ} 44^{\prime}$ and $5^{\circ} 47^{\prime}$ North and Longitudes $6^{\circ} 49^{\prime}$ and $7^{\circ} 03^{\prime}$ East (Atlas Map). The River has over the years seen a massive sand export that continues to erode its banks and gullies. Sand excavation businesses are carried out in the river for building construction and other purposes. The business is very sprawling and has over the years attracted some participants from other towns and villages. It is believed that the state (Imo State) and indeed the local government (Njaba L.G.A) also derive revenues from the sand excavation businesses.

Aside sand excavation, other human activities such as washing and farming take place along the banks of the river hence chemicals from detergents and those used in agricultural lands surrounding the river flow into it during rain fall. Aside providing fishing ground, Njaba River also provides water for domestic purposes to the local population. The pressure on it increases during dry season and festive periods.

Literature on Njaba River is scare hence there is need to ascertain the water quality status of this river taking into cognizance its importance to the local population and the environs. The present study is aimed at assessing the water quality of Njaba River.

\subsection{Sample collection}

II. MATERIALS AND MethodS

The samples were collected from Njaba River at four sampling points. The sampling points were tributary, confluence (where the tributary jointed the main stream), upstream and downstream. The points were at least 90 meters from each other. The sampling materials used were sterile screw capped bottles and the water 
samples were collected from about 4-6cm below the water surface using sterile disposable hand glove. For bacteriological analyses, sterile Durham bottles as described by Nwanebu and Nwabueze [16] were used. At each sampling site, composite samples were collected and pooled together as one sample. The process of opening of bottle caps was quickly done to avoid contamination. Coolers containing ice packs were used to convey the samples to the laboratory for analysis.

\subsection{Physicochemical parameter measurements}

$\mathrm{pH}$, temperature and colour were determined using the methods of HACH [17]. Total alkalinity was done by methyl orange method. Turbidity was done with the method of APHA [18]. Total solid (TS), Total Dissolved Solid (TSS), and Total Suspended Solid (TSS) were done using the methods described by Amadi et al. [19]. Conductivity was carried out using the method of APHA [18]. Hardness was determined using the EDTA titration method. Dissolved Oxygen (DO) was determined using modified Wrinkle`s method, as described in APHA [18]. Biochemical Oxygen Demand (BOD) was estimated using BOD trak test procedure as described by HACH [20]. Chemical Oxygen Demand (COD) was determined by open reflux method. Chloride was done with Argentometric method whereas phosphate and sulphate were determined using colorimetric methods. Metals analysed were determined in water samples using a Perkin Elmer model 306 Atomic Absorption spectrophotometer.

\subsection{Microbial studies}

The Millipore membrane technique as applied by Nwanebu [21] for the examination of water and waste water was adopted for the isolation of bacterial flora. The method described by Blum et al. [22] was used for faecal coliform. Total viable bacteria count and total fungal count were done using the methods of Mill et al. [23].

\section{Results And Discussion}

Table 1. Physicochemical parameters of Njaba River

\begin{tabular}{|l|l|l|l|l|l|}
\hline Parameters & Tributary & Confluence & Upstream & Downstream & WHO standard \\
\hline $\mathrm{pH}$ & $6.38 \pm 0.07 \mathrm{a}$ & $6.16 \pm 0.99 \mathrm{a}$ & $6.19 \pm 0.76 \mathrm{a}$ & $6.22 \pm 0.89 \mathrm{a}$ & $6.5-8.5$ \\
\hline Colour $($ Units $)$ & $0.00 \mathrm{a}$ & $17.07 \pm 1.04 \mathrm{~b}$ & $21.03 \pm 1.95 \mathrm{~b}$ & $22.16 \pm 0.89 \mathrm{c}$ & 15.00 \\
\hline Odour & Odourless & Odourless & Odourless & Odourless & Odourless \\
\hline Taste & Tasteless & Tasteless & Tasteless & Tasteless & Tasteless \\
\hline Temperature $\left({ }^{\circ} \mathrm{C}\right)$ & $23.60 \pm 0.88 \mathrm{a}$ & $25.30 \pm 1.33 \mathrm{ab}$ & $25.70 \pm 0.54 \mathrm{~b}$ & $28.50 \pm 0.78 \mathrm{c}$ & $20-30$ \\
\hline Turbidity(NTU) & $0.01 \pm 0.66 \mathrm{a}$ & $0.99 \pm 0.51 \mathrm{ac}$ & $1.09 \pm 0.33 \mathrm{ac}$ & $1.87 \pm 0.54 \mathrm{ac}$ & 50.00 \\
\hline Total Solid(mg/l) & $500.00 \pm 1.08 \mathrm{a}$ & $4,500.0 \pm 0.96 \mathrm{a}$ & $2,500.0 \pm 0.57 \mathrm{~b}$ & $5,000.0 \pm 0.96 \mathrm{~d}$ & 500.00 \\
\hline TDS $(\mathrm{mg} / \mathrm{l})$ & $400.0 \pm 0.55 \mathrm{a}$ & $3,500.0 \pm 0.54 \mathrm{c}$ & $2,000.0 \pm 0.67 \mathrm{~b}$ & $4,000.0 \pm 0.34 \mathrm{~d}$ & 250.00 \\
\hline TSS $(\mathrm{mg} / \mathrm{l})$ & $100.00 \pm 0.29 \mathrm{a}$ & $1,000.0 \pm 0.80 \mathrm{c}$ & $500.0 \pm 0.22 \mathrm{~b}$ & $1,000.0 \pm 0.87 \mathrm{c}$ & 50.00 \\
\hline Conductivity $\left(\mu \mathrm{scm}^{-1}\right)$ & $699.3 \pm 2.64 \mathrm{a}$ & $4,895.1 \pm 0.66 \mathrm{c}$ & $2,797.2 \pm 1.09 \mathrm{~b}$ & $5,594.4 \pm 0.67 \mathrm{~d}$ & 100.00 \\
\hline Total Hardness $(\mathrm{mg} / \mathrm{l})$ & $60.00 \pm 0.89 \mathrm{c}$ & $50.00 \pm 0.87 \mathrm{~b}$ & $20.00 \pm 0.67 \mathrm{a}$ & $60.00 \pm 0.98 \mathrm{c}$ & 250.00 \\
\hline DO $(\mathrm{mg} / \mathrm{l})$ & $6.00 \pm 0.54 \mathrm{~b}$ & $2.18 .00 \pm 0.53 \mathrm{a}$ & $2.13 .00 \pm 0.66 \mathrm{a}$ & $1.98 \pm 0.43 \mathrm{a}$ & 10.00 \\
\hline BOD $(\mathrm{mg} / \mathrm{l})$ & $0.54 \pm 0.01 \mathrm{a}$ & $5.00 \pm 0.75 \mathrm{~b}$ & $5.00 \pm 0.48 \mathrm{~b}$ & $5.00 \pm 0.87 \mathrm{~b}$ & 10.00 \\
\hline COD $(\mathrm{mg} / \mathrm{l})$ & $0.51 \pm 0.65 \mathrm{a}$ & $4.80 \pm 0.68 \mathrm{~b}$ & $8.53 \pm 0.89 \mathrm{c}$ & $8.34 \pm 0.89 \mathrm{c}$ & 40.00 \\
\hline Total Alkalinity $(\mathrm{mg} / \mathrm{l})$ & $18.05 \pm 0.67 \mathrm{a}$ & $21.00 \pm 0.78 \mathrm{ac}$ & $20.00 \pm 0.22 \mathrm{bc}$ & $19.00 \pm 0.98 \mathrm{bd}$ & 600.00 \\
\hline Sulphate $(\mathrm{mg} / \mathrm{l})$ & $4.45 \pm 1.87 \mathrm{c}$ & $4.40 \pm 0.85 \mathrm{ac}$ & $4.10 \pm 0.99 \mathrm{a}$ & $4.45 \pm 0.89 \mathrm{bc}$ & 250.00 \\
\hline Chloride(mg/l) & $70.00 \pm 0.09 \mathrm{~b}$ & $65.00 \pm 0.11 \mathrm{a}$ & $70.00 \pm 0.62 \mathrm{~b}$ & $65.00 \pm 0.34 \mathrm{a}$ & 1.00 \\
\hline Phosphate $(\mathrm{mg} / \mathrm{l})$ & $25.35 \pm 0.34 \mathrm{a}$ & $28.10 \pm 1.63 \mathrm{~b}$ & $29.55 \pm 0.87 \mathrm{c}$ & $27.45 \pm 0.95 \mathrm{~b}$ & 5.00 \\
\hline
\end{tabular}

Results are means and standard deviations of triplicate determinations. Values with similar alphabets along the same row are not statistically significant at $\mathrm{p}<0.05$.

The $\mathrm{pH}$ of the studied water body is acidic. Human activities may have been the cause of the low $\mathrm{pH}$ observed in the present study. All the investigated points had $\mathrm{pH}$ lower than WHO standard. Intake of water with low $\mathrm{pH}$ could lead to peptic ulcer [10]. Aside the tributary point, colour was detected in other sampling points and at levels above WHO standard. Human activities such as sand excavation could be the cause of the colour detected in the present study. Odour and taste were not detected in any of the sampling points. Increase in temperature of a water body increases the activities of life forms found in the water body [10]. Extent of exposure, shade, etc, is among the factors that affect the temperature of a water body [14]. The temperature values of the present study ranged from $23.60-28.50^{\circ} \mathrm{C}$ and fall within WHO standard. Surface water in which there is a significant increase in level of turbidity after a rainfall is addressed as "flash water" [24]. Aside reducing clarity, such water is often difficult to treat. Turbidity values of the present study were lower than WHO standard. Aside the total solid (TS) in tributary point, the total solid, total dissolved solid (TD), and total 
suspended solid (TSS) values of other points in the present study were higher than their respective WHO standards. The observed high values are clear indication of the influence of human activities such as sand excavation, etc, on the studied river. Consumption of water with high total, dissolved and suspended solids is harmful to the system.

Conductivity values of water have a relationship with total dissolved solid in water [24]. Such relationship was also maintained in the present study. The observed conductivity values of the studied water points were higher than WHO standards. The soap-consuming capacity and scale-forming tendencies of water are measured using water hardness [24]. According to Gray [26], water with hardness value of less than $50 \mathrm{mg} / \mathrm{l}$ is classified as soft and moderately soft when the hardness value is between $50-100 \mathrm{mg} / \mathrm{l}$. The observed total hardness values of this study ranged from $15-60 \mathrm{mg} / \mathrm{l}$. It therefore means that Njaba River water is moderately soft. The observed values were lower than WHO standard. Dissolved oxygen (DO) and biological oxygen demand (BOD) are important for the self-purification process in a natural body [18]. The observed dissolved oxygen (DO) and biological oxygen demand (BOD) values of Njaba River water as observed in this study are lower than WHO standards. Chemical oxygen demand (COD) is important in determining the organic load of a water sample. COD levels of Njaba River water in this study are lower than WHO standard. The various ionic species that contribute to water alkalinity are bicarbonate, hydroxide, phosphate, borate and organic acids [27]. Waste materials that enter a water body may also affect the alkalinity nature of a water body. The alkalinity value of the present study was highest at confluence point, and lowest at tributary points. The observed values for the points were lower than WHO Standard. Aside sulphate level, chloride and phosphate levels of the present study were higher than WHO standards. Sulphate and phosphate in a water body may come from agrochemicals used in farm lands surrounding a water body [25, 28], while chloride may be an indication of pollution from industrial or domestic use [27]. Levels of sulphate and chloride in water bring about laxative effect in human and change in taste of water respectively [29].

Table 2: Metals analysed in Njaba River

\begin{tabular}{|l|l|l|l|l|l|}
\hline Parameters & Tributary & Confluence & Upstream & Downstream & WHO standard \\
\hline Zinc $(\mathrm{mg} / \mathrm{l})$ & $0.026 \pm 0.006 \mathrm{a}$ & $0.021 \pm 0.007 \mathrm{a}$ & $0.067 \pm 0.007 \mathrm{a}$ & $0.013 \pm 0.001 \mathrm{a}$ & 5.00 \\
\hline Lead $(\mathrm{mg} / \mathrm{l})$ & $0.004 \pm 0.001 \mathrm{a}$ & $0.005 \pm 0.00 \mathrm{a}$ & $0.05 \pm 0.002 \mathrm{c}$ & $0.07 \pm 0.00 \mathrm{~b}$ & 0.05 \\
\hline Copper(mg/l) & $0.006 \pm 0.00 \mathrm{a}$ & $0.008 \pm 0.001 \mathrm{a}$ & $0.017 \pm 0.00 \mathrm{bc}$ & $0.011 \pm 0.00 \mathrm{ac}$ & 1.00 \\
\hline Cadmium(mg/l) & $0.003 \pm 0.00 \mathrm{ac}$ & $0.002 \pm 0.00 \mathrm{a}$ & $0.009 \pm 0.001 \mathrm{bc}$ & $0.006 \pm 0.002 \mathrm{ac}$ & 0.01 \\
\hline Mercury(mg/l) & $0.00 \mathrm{a}$ & $0.00 \mathrm{a}$ & $0.006 \pm 0.01 \mathrm{c}$ & $0.002 \pm 0.01 \mathrm{~b}$ & 0.001 \\
\hline Iron $(\mathrm{mg} / \mathrm{l})$ & $0.066 \pm 0.02 \mathrm{a}$ & $0.059 \pm 0.01 \mathrm{a}$ & $0.128 \pm 0.01 \mathrm{~b}$ & $0.087 \pm 0.02 \mathrm{a}$ & 0.30 \\
\hline Manganese(mg/l) & $0.022 \pm 0.01 \mathrm{a}$ & $0.018 \pm 0.01 \mathrm{a}$ & $0.069 \pm 0.02 \mathrm{a}$ & $0.038 \pm 0.01 \mathrm{a}$ & 0.10 \\
\hline Chromium(mg/l) & $0.015 \pm 0.00 \mathrm{a}$ & $0.018 \pm 0.00 \mathrm{ab}$ & $0.046 \pm 0.01 \mathrm{~b}$ & $0.029 \pm 0.00 \mathrm{ab}$ & 0.05 \\
\hline
\end{tabular}

Results are means and standard deviation of triplicate determinations. Values with similar alphabets along the same row are not statistically significant at $\mathrm{p}<0.05$.

The evil effect of having high levels of heavy metals in water consumed by humans as well as aquatic life forms cannot be overemphasized $[8,9,12,16]$. Chromium causes liver, kidney and circulatory disorder; cadmium causes kidney effects; mercury and lead bring about kidney and nervous system disorders; copper has been associated to gastrointestinal irritation. In edible aquatic life forms, copper gives them colours that deter their consumption by humans. Iron and manganese are known to affect the taste of water [29]. The concentrations of zinc, copper, cadmium, iron, manganese, and chromium were lower than their respective WHO standards in the present study. The concentrations lead and mercury at upstream and downstream were higher than their respective WHO standards. Human activities could be the reasons behind the increased levels of these heavy metals at these points.

Table 3: Bioload studies of Njaba River

\begin{tabular}{|l|l|l|l|c|}
\hline $\begin{array}{l}\text { Group of micro- } \\
\text { organism(cfu/ml) }\end{array}$ & Tributary & Confluence & Upstream & Downstream \\
\hline $\begin{array}{l}\text { Total heterotrophic bacterial } \\
\text { count }\end{array}$ & $2.7 \times 10^{4}$ & $3.0 \times 10^{4}$ & $5.2 \times 10^{4}$ & $6.1 \times 10^{5}$ \\
\hline Total coliform count & $0.9 \times 10^{4}$ & $1.2 \times 10^{4}$ & $2.6 \times 10^{4}$ & $3.0 \times 10^{4}$ \\
\hline Total viable bacteria count & $0.4 \times 10^{4}$ & $0.6 \times 10^{4}$ & $1.3 \times 10^{4}$ & $1.5 \times 10^{4}$ \\
\hline Total fungal count & $0.3 \times 10^{3}$ & $0.5 \times 10^{3}$ & $1.1 \times 10^{3}$ & $1.3 \times 10^{3}$ \\
\hline Faecal coliform & $2.0 \times 10^{2}$ & $4.1 \times 10^{3}$ & $7.2 \times 10^{3}$ & $9.2 \times 10^{3}$ \\
\hline
\end{tabular}

Results are means and standard deviation of triplicate determinations. 
Microbial presence in a water body is an index of biological pollution [30]. The result of bioload studies of Njaba River (Table 3) showed high microbial load in the river. From the observed results, total heterotrophic bacterial count was highest in downstream and lowest in tributary point. Coliform bacteria, of which E.coli is a member, indicated the presence of faeces in the river water [31-33]. Total viable bacteria were also high in Njaba River. The presence of faecal coliform in the studied water samples further indicated faecal contamination of the river. The observed total fungal count of Njaba River ranged from $0.3 \times 10^{3}$ to1.3 $\times 10^{3}$ $\mathrm{cfu} / \mathrm{ml}$. The high levels of fungi as observed in different points considered in this study could be related to the levels of decaying organic materials at the points. Microbial load in the studied river followed the order of downstream> upstream >confluence>tributary. The observed difference in levels of the studied organisms could be due to human activities and flood. Human activities and flooding are higher on upstream and downstream points of the Njaba River.

\section{Conclusion}

Conclusively, due to high levels of parameters such as colour, total solid, total dissolved solid, total suspended solid, mercury, lead, and microbial load as observed in the present study, the quality of Njaba River water is poor and should not be consumed without purification. The local population that depends on the studied river water for domestic purposes should take note.

\section{References}

[1]. A Kumar, Water pollution (Nisha Enterprises New Delhi, 2004) 1-331.

[2]. United Nations Environmental Programme, (UNEP ).Environmental assessment of Ogoniland. UNEP Publication. Executive Summary, 2011.p. 3.

[3]. R .N. McNeely, V.P. Neimanis, and L.Dwye, Water quality sourcebook: A guide to water quality parameters (Indland Waters Directorate, Water Quality Branch, Ottawa, 1979).

[4]. World Health Organization (WHO), Environmental Health Criteria, 27, Guidelines on studies on Environmental Epidemiology. Joint Sponsorship UNEP/ILO/WHO. Geneva, 2003

[5]. J.O. Akaniwor, and O. Egwin, Effect of indo food (indomie) industrial effluent discharge on physicochemical properties of new Calabar River in Choba River State. JNES, 3(3), 2006, 174-182.

[6]. P.N.C. Olemeforo, Assessment of the environmental impact of petroleum activities in Port Harcourt and Environs. Unpublished M.Sc. Thesis, Environmental Management and Protection, University of Nigeria, Nsukka, 1994.

[7]. A. T. Odeyemi, A.C. Dada, O.R. Ogubanjo, and M.A.Ojo, Bacteriological, physicochemical and mineral studies on Awedele spring water and soil samples in Ado Ekiti, Nigeria. African Journal of Environmental Science and Technology, 4 (6), 2010, $319-327$.

[8]. B.A. Amadi, P.C. Chikezie, and H.C. Okeoma, H.C, Physiochemical characteristics of Nworie river and its effect on liver function on rats. Journal of Nigeria Environmental Science, 3(3), 2006, 183-187.

[9]. E.I. Akubugwo, and M.K.C. Duru, Biochemical Implications of the Consumption of Water from Otamiri River, Owerri, Imo State, Nigeria. Journal of Emerging Trends in Engineering and Applied Sciences, 2 (6), 2011a, 934-937.

[10]. E.I. Akubugwo, and M.K.C. Duru, Human activities and water quality: a case study of Otamiri River, Owerri, Imo State, Nigeria. Global Research Journal of Science 1, 2011b, 48-53.

[11]. M. Duru, and K. Nwanekwu, Physicochemical and microbial status of Nworie River, Owerri, Imo State, Nigeria. Asian Journal of Plant Science and Research, 2 (4), 2012, 433-436.

[12]. M.K.C. Duru, A.A. Eze, P.C. Odika, B.A. Amadi, and R.O. Chima-Ezika, Consequences of long-term consumption of water from Nworie River (Owerri, Nigeria) on haematological, hepatic, and renal functions using rat model. Biokemistri, 24 (1), 2012,52 - 57.

[13]. O.B. Oloyede, T.O. Sunmonu, O. Adeyemi, and A.A. Bakare, A biological assessment of the effect of polluted water from ASA River in rat kidney, Nigeria Journal of Biochemistry and Molecular Biology, 17, 2003, 25 - 32.

[14]. F.O. Ekhaise, and C.C Anyasi, Influence of breweries effluent discharge on the microbiological and physiochemical quality of Ikpoba River, Nigeria. African J. Biotech, 4 (10), 2005, 1062 - 1065.

[15]. L.M. Ibeh, and C. N. Mbah, Surface water characteristics of urban rivers in Enugu south eastern, Nigeria. World Journal of Biotechnology, 8 (2), 2007,1412-1417.

[16]. F.C. Nwanebu, and R. N. Nwabueze, Regime in occurrence of bacteria of public health significance of some natural water bodies in Imo State, Nigeria. Inter. Res. J. Eng. Sc. Tech. (IREJEST), 1(1), 2004, 23-31.

[17]. HACH, Water analysis handbook, (HACH Company, Loveland, California, 1998).

[18]. APHA, Standard Methods for the Examination of Water and Wastewater 19 (American Public Health Association ,APHA, AWWA. Washington. DC, 2005).

[19]. B.A. Amadi, E.N. Agomuo, and C.O. Ibegbulam, Research methods in Biochemistry 1 ( Supreme Publishers,Nigeria, 2004) 100138 .

[20]. HACH, Water analysis handbook, DR/2010 spectrophotometer manual (HACH Company. USA 1992).

[21]. F. C. Nwanebu, Studies on physico-chemical indicators of pollution in Urashi and Iyiechi Rivers, Imo State, Nigeria. Int. J. Environ. Health Human. Dev, 4(2), 2003, 22-28.

[22]. D. Blum, S. R. A. Huttley, J.I. Okoro, C. Akujobi, B.R. Kirkwood, and R. G. Feachem, The bacteriological quality of traditional water sources in North-Eastern Imo State, Nigeria. Epidem. Inf, 99, 1987, 429-437.

[23]. A. L. Mills, C. Breul, and R. R. Cowell, Enumeration of petroleum Degrading marine and estuarine microorganism by the most probable number method. Can J. microbial, 241, 176, 552557.

[24]. K. L. Ray, B. F. Joseph, L. F. David, and T. C. George, Water supply system , in Water resources association 4 (Washington, D.C. Engineerring. McGraw Hill, 1992) 497567.

[25]. S. O. Adefemi, and E.E. Awokunmi, Determination of physico-chemical parameters and heavy metals in water samples from Itaogbolu area of Ondo-State, Nigeria. African Journal of Environmental Science and Technology 4(3), 2010, $145-148$.

[26]. N.F. Gray, Drinking Water quality problems and solutions (John Wiley and Sons, London, UK, 1994) 43-63.

[27]. R. Shyamala, M. Shanthi, and P. Lalitha, Physicochemical Analysis of Borewell Water Samples of Telungupalayam Area in Coimbatore District, Tamilnadu, India. E-Journal of Chemist, 5 (4), 2008, 924-929. 
[28]. J.N. Egila, and D.N Nimyel, Determination of trace metal speciation in sediments from some Dams in Plateau State. J. Chem. Soc. Nig. 27, 2002, 21-75.

[29]. Viginia Water Resources Research Center A guide to the national drinking water standards and private water systems (Blacksburg, Virginia, 1996).

[30]. W. H. Pipes, Bacterial Indicators of Pollution. ( CRC. Press Inc. Boca Raton FL. 1981) 242.

[31]. P.S. Kumarasamy,R. Vignesh, K. Arthur-James, R. Muthkuman, and A. Rajendra, Enumeration and Identification of Pathogenic pollution indicators in Cauvery Rivers, South India. Res. J. Microbiol. 4, 2009, 540-549.

[32]. S.A.M.S. Dissanayake, S.V.Dias, M.D.C. Perera, and I. A.V.P.Iddamalgoda, Microbial quality assurance of drinking water supplies through surveillance. Proceedings of the Water Professionals Symposium,(WPS'04). Colombo. Sri Lanka., 2004, 141-147.

[33]. C. I. Uzoigwe, and O. K. Agwa Microbiological quality of water collected from boreholes sited near refuse dumpsites in Port Harcourt, Nigeria. African Journal of Biotechnology 11(13), 2012, 3135-3139. 